\title{
DREVENÉ SUDY A ICH VYUŽITIE PRI SKLADOVANÍ NÁPOJOV A POTRAVÍN (STREDOVEKÉ UHORSKO)
}

\author{
JAROSLAV NEMEŠ
}

\begin{abstract}
Abstrakt: Cielom nášho príspevku je poukázat' na využitie drevených sudov v stredovekom Uhorsku. Vyrábali sa z tvrdého dreva a boli stiahnuté obručami z prútia. Kovové obruče sa začali sporadicky použivat' na začiatku 16. storočia. Sudy produkovali debnári vo vel'kých počtoch, dopyt po nich bol v stredoveku mimoriadne vel'ký. Slúžili na skladovanie alebo prepravu najpouživanejších druhov nápojov a potravín. Najčastejšie v nich bolo uchovávané vino, vinohradníci sa bez nich nemohli zaobist'. Ovel'a menej sa spominalo uskladnené pivo a najmenej ocot a olej. Z pevných látok do sudov nakladali obilie a múku, ryby, včelí med a vosk, kamennú sol', kyslú kapustu, ovocie a d'alšie plody, tuk, syr a semená rôznych rastlín. Sudy tvorili dôležitú výbavu hradov aj preto, lebo slúžili na skladovanie vojenských potrieb: smoly a živice, gúl' do diel alebo pušiek, šipov, no predovšetkým troch látok potrebných k výrobe pušného prachu-síry, sanitry a dreveného uhlia.
\end{abstract}

Kl'účové slová: Uhorsko - stredovek - materiálna kultúra-debnárstvo-potraviny.

\section{Wooden barrels and their use in storing liquids and foodstuffs (medieval Hungary)}

Abstract: This contribution discusses the use of wooden barrels in medieval Hungary. Barrels were made of hard wood and were held together by wicker hoops. Metal hoops started to be sporadically used in the early 16th century. Barrels were made by barrel-makers in large quantities as the demand in the Middle Ages was enormous. They were used for the storage and transport of the most widespread liquids and foodstuffs. Barrels were typically used for storing wine and were indispensable for winemakers. Beer was stored in barrels less often, and vinegar and oil even less so. With solid foodstuffs, barrels were used for storing crops and flour, as well as fish, honey and beeswax, rock salt, cabbage, fruits, nuts and berries, fat, cheese and seeds of a variety of plants. Barrels were important part of castle equipment as they also served to store military and defence essentials such as pitch and bitumen, cannon balls, bullets, arrows and, first and foremost, three substances needed for the production of gunpowder: sulphur, saltpetre and wood coal.

Key words: Hungary - Middle Ages - material culture - barrel-making - foodstuffs.

Ak sú témou tohtoročnej konferencie archeológov stredoveku potraviny a ich skladovanie, nemožno obíst' ani „kontajnery“ stredoveku, najpoužívanejšiu obalovú techniku mnohých storočí - teda drevené sudy. Sudy dokázali v dejinách poslúžit' človeku tak ako máloktorá iná vec, podobne ako koleso, voz alebo pluh. Kontajnermi stredoveku a raného novoveku sudy nazvala vo svojom blogu Caroline Tronnier (2015), no určite nebola prvá.

Ciel'om nášho príspevku je poukázat' na využitie drevených sudov pri skladovaní nápojov a potravín $\mathrm{v}$ Uhorsku, vychádzajúc $\mathrm{z}$ analýzy najmä písomných prameňov. K spracovaniu sme využili asi dvesto historických záznamov zo stredoveku, v ktorých sa sudy spomínali. Sústredili sme sa na komodity v nich uložené. Nami skúmaná vzorka, hoci sa dala rozširovat' i d’alej, predstavovala solídny základ pre hlbší výskum. Nezaoberali sme sa však určovaním objemovej vel'kosti jednotlivých nádob, pretože táto otázka by si zaslúžila samostatnú prácu. Hned' na úvod musíme povedat', že v slovenskej, českej a ani v mad’arskej literatúre nie je problematika sudov doposial' moderne spracovaná, lebo stála na okraji záujmu bádatel’ov. $\mathrm{O}$ to bola naša motivácia väčšia. Pri práci sme sa inšpirovali i súčasnou historiografiou, ktorá kriticky prehodnocuje výsledky starších výskumov a spochybňuje často preberané fakty (napr. Lukačka 2016; Slivka 2016; Plaček 2017). Dospeli sme tak k zaujímavým výsledkom bádania širokého a univerzálneho využitia sudov v uhorskej praxi.

\section{Výroba sudov ako remeslo}

Práca debnárov patrila $\mathrm{k}$ najstarším špecializovaným remeslám $\mathrm{v}$ odvetví spracovania dreva. Debnárstvo mohlo pochádzat' od Keltov a Germánov a dostalo sa k Rimanom, lebo sa 
udomácnilo skôr na území severne od Álp než v Stredomorí. Medzi vel'ké debnárske výrobky môžeme zaradit' sudy, vínne škopky, rôzne kade či kúpel'né vane. Pre obchodovanie však bola najatraktívnejšia výroba sudov, lebo boli hojne požadované ako univerzálny obalový materiál stredoveku a na začiatku novoveku. Okrem toho debnári vyrábali aj menšie drevené výrobky, ako boli vedrá, misy, korytá, črpáky, poháre a d'alšie. Menšie drevené výrobky boli zhotovované viac pre domácnosti ako pre dial'kový obchod (Baum 1999, 490-492).

Debnárov môžeme rozlíšit' aj podl'a toho, či produkovali vel'ké, objemnejšie nádoby, hlavne „mokré“ sudy, ktoré vyrábali najmä z tvrdého dreva, alebo menšie tzv. „suché“ nádoby, zhotovené najmä z „bieleho“ dreva smreka, jedle a topol'a. Remeselníkov preto rozdel'ovali na vel'kých debnárov (robili sudy a kade) a malých debnárov (vedrá, kanvice, poháre); čiernych debnárov (spracovávali dubové drevo), červených debnárov (bukové drevo) a bielych debnárov (ihličnaté drevo); taktiež mokrých a suchých debnárov atd'. (Packheiser 2008, 34). Drevospracujúce remeslá a cechy sa stále viac špecializovali, a preto sa od seba oddelovali, napríklad ako Küfer a Kübler vo Württembersku, alebo bečvář a bednář v Čechách a na Morave a pod. (Janotka-Linhart 1987, 141-142; Válka 2014, 115).

Práca s drevom bola náročná ako finančne, tak fyzicky. Na výrobu sudov používali vopred narezané dosky štandardnej vel'kosti, tzv. dužiny (Böttcherholz), ktoré bývali často dovážané z vel'kých dial'ok, ak si ich sami nevyrobili doma. Drevo nesmelo byt' hnilé alebo červivé, nemalo mat' žiadne uzly alebo zlomy. Dužiny potom opracovávali, vlhčili a sušili, vypal'ovali a obručami debnili do spoločných oblých tvarov. K nim prirábali okrúhle ploché boky - presný postup opísali Janotka-Linhart $(1984,110)$. Okrem spomínaného najčastejšie využívaného dubového dreva to mohli byt' buky a borovice, $v$ južnej Európe bolo spracovávané i gaštanové drevo. Pre st'ahovanie dužín boli využívané brezové, lieskové alebo vŕbové prúty vo forme obručí, alebo neskôr kováčmi dodávané drahšie železné obruče (Baum 1999, 490-492). Sudy nemali pretekat', nemohli sa opravovat', pri výrobe sa vyžadovala presnost' a precíznost'. Hoci kvalita práce bola rôzna, závady boli neprípustné.

Je pravdepodobné, že výroba vel'kých sudov bola vykonávaná iba na objednávku, no sudy štandardnej vel'kosti zhotovovali do rezervy pre vol'ný predaj na trhu. Objemy produkcie jednotlivých cechov vo vel'kých mestách mohli dosiahnut' až niekol'ko tisíc sudov ročne. Menšie cechy pracovali v prospech vinárov, sládkov alebo stálych obchodníkov. Debnári museli identifikovat' svoje výrobky vlastnou značkou.

Pracovný čas debnárov bol v mnohých mestách - pravdepodobne vzhl’adom k riziku vzniku požiaru a hlukovej zát’ǎe pre miestnych obyvatel'ov - prísne regulovaný. Mestá často obmedzovali počet cechov či debnárov. Pravdepodobne z rovnakých dôvodov sa viaceré mestá (napríklad Frankfurt alebo Brémy) snažili debnárov usadit' v určitých uliciach s mnohými obmedzeniami (Baum 1999, 490-492). Z takýchto štvrtí a ulíc vychádzal typický buchot alebo dym, čo mohlo výrazne obt'ažovat' susedov. Zvýšená potreba výroby sudov bola tam, kde sa obchodovalo s vínom, pivom, rybami alebo kožami.

V Uhorsku sa pre pomenovanie remesla využívali najmä latinské termíny dole(i)ator, dolifex, tunnarius, cuparius, ligator vasarum, no v mestách poznáme aj nemecké pojmy (Böttcher, Faßbinder, Binder, Büttner, Schäffler, Küfer a iné). V novoveku sa stretávame i s názvami v mad'arčine kádár, pintér a bodnár.

Najväčšími drevenými nádobami boli sudy rôznych rozmerov pre skladovanie tekutín (víno, pivo, ocot, olej a i.) alebo pevné látky (obilie, múka, ryby, koža, popol atd’.). Používali sa aj ako jednotka určitej vel'kosti a balenia. Štandardizácia ich objemu však prebehla až v novoveku a mala charakter miestnych súkromných opatrení. Vel'kost' bola odvodzovaná od sudov štandardných rozmerov lokálnej normy alebo od vel'kosti sudov významného obchodného partnera. Rozmanité boli i vel'kosti sudov na tekuté a pevné produkty, no dramatické zmeny vo vel'kostiach možno odlíšit' až od 15. storočia (Witthöft 1999, 303). Debnári boli povinní pracovat' podl'a stanovených mestských či lokálnych mier, ktorých nedodržiavanie mohlo byt' potrestané dokonca odobratím remesla (Janotka-Linhart 1987, 142). V stredovekých historických prameňoch síce možno terminologicky rozlíšit' istú diferenciáciu vel'kostí sudov, no nebola absolútna, 
ale relatívna. Pojmy „vel'ký sud - sud strednej vel'kosti - súdok“ by sme mohli v latinských, nemeckých a mad’arských prameňoch špecifikovat' takto:

vas, vasa (maior) - vasa media (vasculum) - tunella

Faß - Tonne (Küfe, Küffe) - Tonlen (Tonnlein)

hordó - kishordó, bödön-hordócska

Medzi jednotlivými pojmami ale neboli pevne vymedzené hranice, výrazom „,vasculum“ mohol byt' v stredoveku pomenovaný aj sud štandardnej strednej vel'kosti, aj malý súdok. Menšie sudy, súdky, sa v prameňoch spomínali najčastejšie vtedy, ak sa hovorilo o pevných a sypkých materiáloch, zriedkavejších či cennejších komoditách, akými boli loj, med, vosk, živica, sol', síra atd'.

Hoci sa $\mathrm{v}$ príspevku zaoberáme iba nádobami zhotovenými z dreva, v písomných dokumentoch sme našli i sudy cínové, strieborné, olovené, kovové (železné) a medené. Posvätené oleje, krizmu, uchovávali v sakristiách kostolov hlavne v strieborných pozlátených nádobách, ako to bolo na hrade Vyšehrad v roku 1490 (vas pro unctione argenteum auratum; Nógrády 1998, 179). Pri uchovávaní posvätenej vody v kostoloch a kaplnkách sa využívali najmä nádoby z olova. V inventári opátstva Bélapátfalva mali v roku 1508 uchovanú posvätenú vodu v olovenom súdku (vasculum plumbeum pro aspersione aque benedicte; EHP, 344). V mandáte gubernátora Jána Huňadyho z 1. júna 1452 sa v súvislosti s dlhmi Bratislavy spomínalo okrem iných vecí i 16 kovových súdkov (vascula caminorum) a 15 tisíc šípov, ktoré mali rovnako použit' na splatenie dlhu (MNL, DL-DF 107548). V účtovnej knihe budínskeho Nádašdyho domu sa 6. januára 1531 spomínala kúpa jedného oloveného súdku za 20 denárov (emi ex plombo vnum vasculum pro theryek den. XX; Baraczka 1966, 256).

\section{Preprava sudov}

Vinohradníci a vinári požadovali na vel'ké objemy vína vel'ké počty sudov. Vyrábali ich debnári žijúci najmä v lesnatých oblastiach, kde mali remeselníci poruke dostatok tvrdého dreva. Napríklad Vesprémske biskupstvo kupovalo sudy na trhoch z oblastí pozdíž rieky Drávy (Holub 1960, 199). Drevené sudy boli v stredoveku všeobecne menšie, ako ich poznáme dnes, a to nielen kvôli technickým t’ažkostiam pri výrobe vel'kých sudov, ale aj kvôli st’aženým podmienkam pri preprave vinárskych zásielok vel'kých objemov. Na prepravu boli potrebné aspoň dva kone s vozom, a to aj na t’ahanie stredne vel'kého suda. Prepravovanie vínnych sudov na vozoch spomínala aj listina Belu IV. o udelení trhového mýta (tributum fori) pre Kláštor Panny Márie na Margitinom ostrove $\mathrm{z}$ roku 1255 . Ak hovorili o preprave troch sudov vína na jednom voze, museli byt' menších rozmerov (CDH IV/2, 311). V listine Vesprémskej kapituly z roku 1444, ktorá riešila majetkové spory, sa hovorilo o odnesení desiatich vel'kých a sedemdesiatich malých sudov vína. Vel'ké sudy sa spomínali ako „decem magna vasa vini vulgariter boch dicta“, teda vel'ké sudy sa l’udovo nazývali „bočky“ (Holub 1960, 198, pozn. 106). Počet prepravených sudov na jednom voze preto museli prispôsobit' ich objemom či hmotnosti.

Ako uviedol mad’arský historik József Holub $(1960,199)$, železné obruče na sudoch v stredoveku ešte neboli, používali sa obruče vyrobené z prútia. Sudy preto nazývali zväzovanými sudmi (vasa ligare). Dužiny boli najčastejšie stiahnuté do kónusu surovým brezovým alebo lieskovým prútím, spojeným do oblúka čerstvo stiahnutou kôrou stromov. Miroslav Válka (2014, 115) uvažoval o obručiach z prútia, ktorých rozštiepené konce sa prevliekli a zasekli, pripustil aj prúty z vŕby. Rákosím či kôrou sa vypíňali aj prípadné netesnosti medzi jednotlivými drevenými latkami a dnom. Obruče z prútia však neboli pevné a odolné, nevydržali dlho kymácanie na cestách a v nimi stiahnutých sudoch sa nemohli prepravovat' vel'ké objemy, lebo nemali vel'ké priemery. Nedokázali nimi pevne zviazat' vel'mi široké sudy. Ked' sudy prevážali na konských povozoch po nerovných a nespevnených cestách, na jar a jeseň navyše zablatených, mohli sa rozpadnút', poškodit' alebo rozbit'. V stredoveku totiž nepoznali ani odpružené (pružinové) vozy. 
Vyobrazenie vozu určeného k preprave sudu, ktorý t’ahal konský dvojzáprah, môžeme vidiet’ na jednej z tabul'ových malieb gotického krídlového Oltára sv. Mikuláša z kostola v Lúčkach (okres Žiar nad Hronom). Oltár je dnes majetkom Mad’arskej národnej galérie v Budapešti. Jeho autor, umelec známy ako Jánosréti mester, ho vytvoril okolo roku 1476. Otvorená korba štvorkolesového voza pozostávala zo štyroch súbežných tyčí upevnených v smere jazdy, medzi ktoré sa drevený sud zachytil (vid' Cidlinská 1989, 58-59; Keller 1990, 187-200; Kerny 1992, 115-120). V európskej ikonografii obdobia stredoveku poznáme viac príkladov takýchto jednoduchých vozov naložených jedným, dvoma či troma sudmi. Zachovali sa tiež mal'by alebo rytiny klasických dvojkolesových vozíkov s rovným platom, na ktorom bol naložený jeden alebo viacero sudov. Vkladala sa medzi ne slama, aby sa navzájom nepotíkli.

Menej problémovú prepravu na cestách zabezpečili až sudy stiahnuté kovanými železnými obručami. Kedy sa začali v Uhorsku používat? Ked’že na hrade v Jágri boli v roku 1503 dlžní poslat' víno do Talianska, zabezpečili pre Jágerský hrad dva vozy za 11 zlatých a 25 denárov (duos currus pro castro, quos cum vinis ad Italiam debuissem mittere fl. $X I d$. $X X V$ ). Na to, aby mohli víno na d’alekú cestu každoročne vozit', zakúpili v roku 1505 štyri sudy so železnými obručami ,vasa ferrata“ a dva d’alšie menšie sudy za 4 zlaté a 60 denárov (vasa quattuor ferrata cum tunellis duabus admittendum ipsa vina ad Italiam, emit fl. IIII d. LX; EHP, 173).

V kanižaiovskom urbári z roku 1519 stálo, že vinári na panstve Sárvár mali k dispozícii sudy stiahnuté kovovými obručami: „Magistri vinearum debent disponere vasa vulgo abronchozny" (MNL, DL 37007, fol. 79v; Holub 1960, 199, pozn. 107). Staršie zmienky o ich výrobe a používaní vo vinárstve sme zatial' nenašli. Až kovom stiahnuté nádoby predstavovali dosiahnutý pokrok, mohli byt' väčších priemerov a vydržali prepravu na dlhšie vzdialenosti.

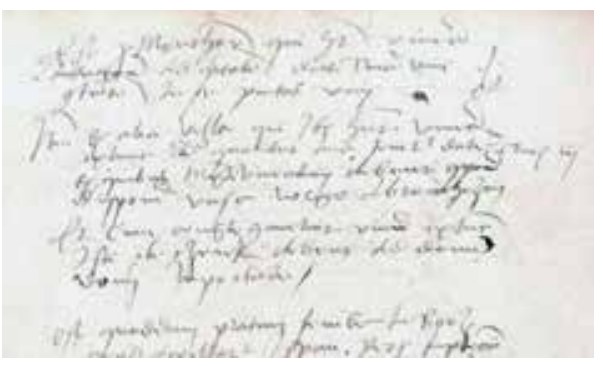

Obr. 1. Zmienka o sudoch so železnými obručami. Podl’a Sárvár 1519, 7. riadok dokumentu (MNL, DL 37007, fol. 79v).

Abb. 1. Erwähnung von Fässern mit Fassreifen aus Eisen. Nach Sárvár 1519, 7. Zeile des Dokumentes (MNL, DL 37007, fol. 79v).

\section{Sud vína}

Najčastejšou komoditou naplnenou v sudoch bolo víno. Dlhodobo sa dalo uchovávat' takmer výlučne v nich. Ďalšie drevené nádoby rozličnej vel'kosti ale vinári potrebovali pri spracovávaní hrozna a muštu. Najstaršie zápisy z Uhorska o uskladňovaní vína $\mathrm{v}$ sudoch máme zo začiatku 12. storočia. Od roku 1109 , teda ešte z čias král'a Kolomana, mal Kláštor Panny Márie vo Veszprémvölgy dostávat' z viníc dediny Szárberény (dnes Vörösberény) každoročne jeden sud vína s objemom 60 gbelov (60 cubulos). Dosvedčovala to listina z 20. mája 1383 (VER, 306-308 č. 788).

Niektoré historické pramene dokladajú vysoký počet sudov. Boli bud' väčšie, stredné alebo menšie, víno v nich bolo bud' staré, alebo nové. Sudmi vína mohli zaplatit' dane, desiatok, splatit' dlh, vykúpit' majetok zo zálohu či vyplatit' odškodné za ujmu, ktorú niekto utrpel. Napríklad v listine zo 6. mája 1416 sa spomínali dva sudy vína ako odškodné (ZsO V, 494 č. 1854). Bol to majetok, ktorý si zachoval svoju hodnotu aj po dlhých rokoch.

V ktorých písomných prameňoch nájdeme vysoké alebo vyššie počty sudov? Pri výbere cirkevných desiatkov vo Vesprémskej diecéze zapísali 25 sudov vína (10. júla 1298, viginti quinque tunellarum vini; Kis-Petrik 2008, 42-43), o sto rokov neskôr od niektorých obcí na Zemplíne vybrali 24 sudov vína (30. januára 1399, 24 tunella vini; ZsO I, 628-629 č. 5692). Početných záznamov bolo mnoho. V zápise bratislavskej súdnej stolice z 30. augusta 1413 sa spomínalo šest' menších sudov vína (sex vasorum parvorum vini; ZsO IV, 239 č. 1019).

Jednotlivé i početné sudy vína odkazovali i v testamentoch (vas vini, niekde tunella vini). Ostrihomský prepošt Ladislav v roku 1277 poručil štyri sudy vína, ktoré mal vo svojom dome, 
tiež ostatné, ktoré boli uskladnené mimo jeho bydliska (MES II, 71 č. 54). Matúš, kanonik kapituly v chorvátskej Čazme, zostavil v roku 1483 svoj testament, v ktorom okrem duchovného dobra rozdelil mnoho vecí. Svojmu spolubratovi lektorovi z kapituly zanechal plný súdok octu, ktorý mal uložený v pivnici (unum vasculum aceti). Tam mal d’alších trinást' vínnych sudov (vasa tredecim), či už plných, alebo prázdnych, ktoré zanechal okrem jedného vel'kého plného suda Kostolu sv. Margaréty a svojmu nástupcovi v úrade. Pridal k tomu aj lis na hrozno (tholcular vini) a trinást' d’alších nádob (kadí, dolea sunt tredecim). Vel'ký sud vína (magnum vas vini), ktorý mal uschovaný v pivnici domu, zanechal spolu so stovkou gbelov prosa (centum cubulos milii) Baccovi a jeho bratom (MNL DL-DF 35711; Mályusz 1929, 303-304). Dávid z Dubového (Dombó, dnes na Ukrajine) vo svojom testamente z roku 1504, spísanom na štyroch stranách, odkázal dva sudy svojho vína dvom farárom $\mathrm{v}$ dvoch dedinách za odslúženie zádušných omší. Každý z nich mal dostat' po jednom. Víno tak poslúžilo duchovným ciel’om (BCsL, 172). Briccius, dekan zo Szikszó, spomínal v roku 1517 v testamente 19 prázdnych sudov, ktoré patrili k jeho majetku (Kemény 1891, 39; Mályusz 1971, 134-135).

Bez vína sa nemohli zaobíst' ani rehol'níci v kláštoroch. V listine královnej Márie, vydanej v Košiciach 26. mája 1419 pre kartuziánov v Lechnici, sa hovorilo o každoročných dodávkach dvoch sudov vína pre nich z mesta Szikszó (duo vasa sive duas tunellas vini). Nerozlišovalo sa tu medzi názvami sudov vasa a tunella (ZsO VII, 161-162 č. 517). Kláštor pavlínov Všetkých svätých $\mathrm{v}$ Balatonszemes mal dostávat' každý rok po vinobraní z predanej vinice desat' sudov vína, ako o tom hovorila listina z roku 1438 (Molnár 1975, 224). V listine krála Mateja z 8. januára 1472 sa spomínalo mesto Miškolc v súvislosti s kláštorom pavlínov v Diósgyőri a ich každoročnou dodávkou desat' sudov vína (MNL, DF 248047; Gulyás 2014, 43-44).

Cistercitské opátstvo Trium fontium (Bélapátfalva) môžeme spomenút' aj v súvislosti s vinárstvom, nachádzalo sa totiž vo vinohradníckom kraji. Začiatkom 16. storočia podporovali i výrobu drevených sudov. V roku 1504 sa v účtovnej knihe popri viacerých starších sudoch vína spomínajú aj nové prázdne sudy určené pre vínne desiatky (nova vasa vacua pro decimis), ktoré kúpili za 49 zlatých. V roku 1505 predali jeden sud vína za 10 zlatých, podla ceny musel byt' väčší. Z výnosu tohto predaja zabezpečili nevyhnutné potreby, okrem iného dali opravit' svoje vozy. Tie potom použili na prepravu vínnych sudov. Ďalších 66 zlatých obetovali na opravu kláštorných striech, niekol'kých dverí - kladiek a kl'účov - a na otesané dosky určené na výrobu sudov (ad emendum tignas pro vasis laborantibus). Do materiálu potrebného k výrobe sudov investovali aj v d’alšom roku, a to 10 zlatých. Navyše predali ešte dva sudy vína, aby za utŕžené peniaze nakúpili nové drevené sudy (EHP, 356-357).

Zaujímavý pohl'ad na využívanie sudov vo vysokých počtoch nám poskytol inventár královského hradu Vyšehrad zo 7. augusta 1490. Mnohé veci, ktoré sa nachádzali na hrade, by sme mohli rozdelit' na materiálne, teda hmotný tovar a potraviny, resp. veci potrebné k obžive. Hradné panstvo do sudov najčastejšie napíňalo víno. V Hornom a Dolnom hrade Vyšehradu bolo v roku 1490 spolu 23 a devät' sudov vína a v ned’alekom Královskom „Matejovom“ paláci ešte d’alších osem sudov vína. Dohromady sa tam nachádzalo 40 sudov vína (Nógrády 1998, 179-180).

Dôležitým prameňom k vinárstvu je i účtovná kniha jágerského biskupa Hypolita Esteiho z rokov 1500-1508. Obsahuje totiž stovky údajov. Vel'ké objemy vína uskladňovali na Jágerskom hrade, kam zvážali vínne desiatky (decima vinorum), ak tieto neboli zaplatené v zlatkách. $\mathrm{Z}$ úrody viníc roku 1500 našiel správca pri inventarizácii pivnice spolu 89 sudov vína, z nich 63 vasa integra a 26 vasa media (EHP, 145-146, 26. 6. 1501). Najvyššie počty sudov však spísali pri zvoze vína z rôznych miest a obcí dňa 4 . júla 1501 . Zoznam obsahoval počty $34,35,53,89$ a d’alšie, čo tvorilo spolu summa vasa integra 354, summa vasa media 70 . K nim pripísali ešte z d'alších obcí 282 sudov vasa integra a 522 sudov vasa media. Teraz musíme zvýšit' pozornost', pretože sa zdá byt' neuveritel'né, že spolu vyzbierali 636 sudov vína ,integra“ a 592 sudov vína „media“. Takže dopyt po výrobe sudov musel byt’ pri Jágri v roku 1501 obrovský (EHP, 146).

Sami vyberači vínnych desiatkov tiež neobišli naprázdno, počty za odmenu im daných sudov boli pomerne vysoké, v roku 1501 dostali 25 sudov a v marci 1502 zasa 36 sudov vína. Pri 
opise vel'kostí sudov nájdeme vo výkazoch predovšetkým tri termíny: celý sud vína (vas vini integrum), polovičný sud vína (vas vini medium), sud prostredne vel'ký (unum vas vini mediochris). Žial', ani z tohto zápisu nie je možné získat' úplne presnú predstavu o jednotlivých kategóriách drevených sudov (EHP, 100-101).

Rovnako zaujímavé boli správy o predaji vína z pivníc v Jágri z roku 1501, pri ktorých sa nachádzali zaznačené kúpne ceny v zlatých a denároch. Sudov predali mnoho, bud' menších (napr. triginta quattuor vasorum vini minorum), alebo strednej vel'kosti (napr. trium mediorum vasorum), či vel'kých (napr. unius magni vasis vini). Takže skutočná predstava o ich vel'kosti je približná. Ani utŕžené sumy peňazí nič nehovorili o objeme sudov, lebo boli stanovené rôzne. Pohybovali sa asi od 5 zlatých za strednú vel'kost' po 8 zlatých za vel'ký objem. Na zozname bol však aj vel'ký sud vína predaný za 9 zlatých ( $f$ l. novem pro venditione unius vasis magni in Halas; EHP, 143, 25. 7. 1501), dokonca d’alší predaný za viac ako 10 zlatých (recepi ex venditione trium vasorum vini integrorum fl. triginta unum et d. viginti novem; EHP, 148, 12. 1. 1502), či až 11 zlatých a 16 denárov (pro uno integro fl. undecim d. sexdecim; EHP, 151, rok 1501). Naopak, nájdeme i predaj stredného suda vína za 3 zlaté a 50 denárov (EHP, 144, 24. 8. 1501) alebo za 3 zlaté (EHP, 145, 28. 9. 1501), či naopak za 8 zlatých a 32 denárov (EHP, 143, 25. 7. 1501). Takže vel'kosti predaných sudov vína a utŕžené peniaze za ne sa výrazne odlišovali, ceny boli trhové a nejestvovala priama úmera medzi objemom predaného sudu vína a jeho cenou. Ak sa v účtovnom zozname z roku 1502 písalo o predaji malých sudov vína, cena za ne často nebola nižšia než za iné väčšie sudy (napr. pro uno parvo vase solvit fl. sex et d. triginta unum; EHP, 149).

Medzi účtovnými zápismi Jágerského biskupstva nájdeme i správy o vrátení prázdnych sudov, napríklad v roku 1501 doviezli na hrad 39 sudov (dicta vasa sunt restituenda, scilicet triginta novem vacua castro Agriensi; EHP, 143, 25. 7. 1501). V roku 1503 mali dat' v troch obciach Gyöngyössolymos, Gyöngyöspüspöki a Gyöngyös vyberačovi desiatkov Andrejovi spolu 106 sudov vína. Niektoré z nich predtým vyprázdnili, ked’že víno sa už vypilo. V d’alšom roku mali prázdne sudy doplnit' (EHP, 163). Podl'a d'alších údajov v účtovnej knihe bolo v sudoch červené víno (unum vas vini rubei; EHP, 179), no našlo sa i víno nie vel'mi dobrej kvality (vinum non valde bonum; EHP, 178), alebo dokonca vel'mi zlé víno, nepitné, ktoré sa podl'a pisára nehodilo ani na charitu pre chudobných (alia vina non sunt equaliter, nec vasa, ne possibilitas pauperum et opportet super eos misericordiam facere; EHP, 181).

Plné alebo prázdne sudy vína boli najčastejšie ukladané v pivniciach. Tam však pre ne niekedy neboli vytvorené vhodné podmienky, často boli vlhké, alebo do nich zatekalo. Stalo sa, že v nich stála spodná voda a boli zatopené, preto museli byt' evakuované. V roku 1507 museli prenášat' osem sudov vína zo zatopených pivníc v dvoch zemplínskych obciach na Jágerský hrad (octo vasa integra, que erant collocata cum aliis in Besegnu et Kerestwr, quia cellaria fuerunt ab aquis repleta et dari non potuit auxilium, omnibus sexdecim vasis cum medio et sic octo sunt perdita et alia importata ad castrum; EHP, 289).

Cenným prameňom je inventár panstva jágerského biskupa z roku 1508, spísaný Tadeášom Lardom, jágerským kanonikom-kustódom. V úvode dokumentu sa nachádzal „vínny účet“ panstva. Sudy vína boli spočítané podla jednotlivých pivníc alebo iných skladov (bolthum = zaklenutá miestnost'), $v$ ktorých boli uložené. V pivnici pri kuchyni evidovali 23 sudov, v troch vel'kých, konkrétne pomenovaných pivniciach našli 55, 15 a 26 sudov, vo viacerých skladoch ležalo tri, osem, sedemnást', jeden, dvanást', štrnást' sudov atd'. Niektoré z vykazovaných nádob boli polovičnej vel'kosti. Menší sud vína mali odložený aj v akejsi neznámej kamennej diere (in fovea lapidea). Celkom bolo na biskupskom panstve v Jágri uskladnených 175 plných sudov vína, z nich bolo 32 sudov polovičných. Prázdnych sudov bolo 126 a menších prázdnych sudov 22 (EHP, 340-341).

Podobne by sme mohli pokračovat' d’alej, účtovná kniha jágerského biskupa Esteiho z rokov 1500-1508 poskytuje k výskumu ešte vel’a možností. Cenným prameňom k debnárstvu a vinárstvu však môžu byt' i d'alšie zachované hradné inventáre.

Do opisu škôd spôsobených vojenským drancovaním hradných panstiev Lipovec a Jastrebarsko pri Záhrebe, ktoré sa uskutočnilo krátko po 16. februári 1520, zaznamenali aj zničené 
vínne sudy, na zem vyliate či vojakmi vypité víno z pivníc jednotlivých obyvatel'ov. Straty boli vykázané podl'a počtu sudov alebo počtu gbelov (cubulos), ktoré obsahovali. Medzi škody zaradili jeden vypitý sud vína s objemom 25 gbelov, vyliatych 28 gbelov vína, vyliatych 32 gbelov, zničené sudy a 70 gbelov vína vypitých alebo vyliatych na zem, rozbité štyri sudy obsahujúce 146 gbelov vína, rozbité tri sudy obsahujúce 126 gbelov vína vytečeného do zeme, po zaseknutí vytečených 19 gbelov vína a jeden súdok octu, 40 gbelov vína vytečených zo sudov do zeme a dva zničené prázdne sudy, rovnako 35 gbelov a d'alších 40 gbelov škody. Týmto spôsobom vyčíslili vážne straty na sudoch a víne (FCsO, 323-339 č. 315).

Čo skladovali v pivnici hradu Gyula podl’a zachovaného inventára zo 17. júla 1528? Spolu osem sudov vína, z ktorých jeden bol menší. Tiež vlastnili jeden sud octu (vas aceti in eodem cellario). Iných trinást' sudov vína mali v pivnici uskladnených obyvatelia mesta (xiii vasa civium civitatis), ich presnú evidenciu viedol provízor hradu. Spolu 73 prázdnych sudov zobrali a uchovávali v nich múku, ale nevedno kde, d’alších štrnást' prázdnych sudov zostalo v stodole hradu (xiiij vasa vacua in stabulo foeni castrum; GVO, 133 č. 148).

V zachovanom inventári dnes už neexistujúceho hradu Szenyér v Šomod'skej župe z 13. mája 1530 nájdeme medzi mnohými položkami najmä víno rôznej kvality. Nachádzalo sa v pivnici paláca. Dobrého vína bolo dvanást' sudov (in uno cellario in castello consistunt vina bona vasa XII), štyri sudy vína mali odložené pre koscov na žatve (messaria mercenariorum falcatorum vasa IIII), ale sedem sudov obsahovalo „zrejúce vína nijakej hodnoty úplne napadnuté zápachom a skysnutím" (vina nullius estimationis valitura pene feditate muscedine infecta vasa $V I I$ ). Prázdnych sudov vlastnili 28, mali tam i jeden malý súdok octu (acetum parve estimationis vas I). Ďalej sa na hrade nachádzalo pät' sudov múky (farine vasa $V$; Borsa 1986, 73-74).

\section{Sud piva}

Pivo sa v stredovekých písomných správach spomínalo výrazne menej ako víno. Na jednej strane pivo nebolo tak často používaným nápojom, na druhej strane jeho skladovanie bolo časovo obmedzené a vyžadovalo si rýchlejšiu konzumáciu. Ak sa v prameňoch nachádzalo, tak iba všeobecne, zvyčajne nebolo presne špecifikované (lat. cervisia, cerevisia). Našli sme však aj označenie pšeničné pivo (cerevisia triticea) či čierne pivo (cerevisia nigra). Mohlo byt' naplnené v sude (vasa cerevisie) alebo súdku (tunella cerevisie, vasculum cerevisie). Častejšie sa $\mathrm{v}$ písomných zmienkach spomínalo v rozličných mierach, napríklad vo vedrách (ydriis/indriis cervisie), $\mathrm{v}$ gbeloch (cubulos cerevisie), pintách (octuale cerevisie, cerevisie pintha), flašiach (lagena cerevisie) či väčších krčahoch (cantharos cervisie magnos). V stredovekých dokumentoch sa spomínali aj pivné kvasinky (saccharomyces cerevisie).

Najstaršiu zmienku o pive sme našli z roku 1210, kedy kanonik z Győru menom Opus spomenul vo svojom testamente trojročného býka, sto chlebov a sud piva, ktorý mal dat' každoročne jeden z jeho verných servientov kostolu za vykonanie zádušnej omše (CDA I, 105-106 č. 60). Takto sa to dialo dlhé roky, lebo túto mimoriadnu povinnost' zahrnuli aj do konfirmačnej listiny Ondreja II. pre Panonhalmu z roku 1221 (CDA I, 171-175 č. 96).

Varenie piva a jeho čapovanie patrilo v stredovekej spoločnosti medzi privilégium. Jasovský konvent premonštrátov v roku 1421 prepísal listinu král’a Žigmunda, ktorú vydal mestu Košice. Hovorilo sa v nej, že do vzdialenosti jednej míle nik iný pivo varit' nesmel, ani ho nemohol vystavit' na predaj alebo ho za peniaze čapovat', ani samotné ho v sude predávat' (cum vasis cumque vendere), a to pod hrozbou trestu odňatia tohto piva (sub pena ablationi huiusmodi cerevisie; ZsO VIII, 388 č. 1287).

V inventári domu Jána Korvína v Banskej Bystrici sa v roku 1494 nachádzali okrem iných vecí aj štyri súdky piva (quatuor vascula cerevisie) a šest' sudov nakladanej kapusty (item sex vasa caulium). Výbavu jeho domu a potraviny spísali vyslaní meštania za prítomnosti mestského notára (OF I, 626-627).

V torze účtovnej knihy slobodného král’ovského mesta Prešov z roku 1429 sa pivo a sudy piva spomínali na viacerých miestach. Magistrát tohto mesta pravidelne vynakladal prostriedky 
na to, aby zabezpečil pivo pre svojich obyvatel'ov (pro cerevisia ad usum civitatis, pro usu et honore civitatis). V zmienenom roku vynaložili na zakúpenie piva financie spolu osemkrát, vždy ich vypočítali v denároch $(20,55,28$ atd'.). Išlo rozhodne o menšie sumy peňazí, než aké mesto vynakladalo na nákup vína (EVL I, 93-103 č. 220). Rovnako ako s peňažnými odmenami za vykonanú prácu, tak aj v nákupe piva vznikol pracovníkom v Prešove zakorenený zvyk. Napríklad v roku 1429 tí, čo pálili vápno, dostali za jednu pec plnú vápna okrem 60 zlatých aj jednu celú slaninu, jeden polsud piva (pro medio vase alias eyn halb legel cervisie) a iné veci (Iványi 1917, 247). V roku 1446 zasa murárom vyčlenili 58 denárov na nákup piva (item pro medio vase cerevisie muratoribus den LVIII; Iványi 1918, 117). Ďalšie roky nakupovali sudy piva rovnako, no dali ho aj lámačom kameňa (fractori lapidum) a d’alším pracovníkom v meste.

Sudy piva riešili v Prešove aj v roku 1440, tentoraz v súvislosti s mýtnym sporom pri hornej bráne a s vyrubením novej colnej tarify (de uno vase cervisie tres denarios etc.). Pre porovnanie, poplatok za sud vína bol dvojnásobný než za sud piva (de una tunella sex denarios et de dimidio tres denarios; EVL I, 119-121 č. 269).

Protokoly mesta Prešov z rokov 1424-1509 obsahovali tiež viacero zaujímavých údajov k inventárom domov. Podl'a zápisu z 5. februára 1499 predal Juraj Henckel z Levoče s manželkou Barbarou dom v Prešove so všetkými príslušnost’ami ned’aleko Kostola sv. Mikuláša za 158 uhorských zlatých. Dom by nebol ničím zvláštny, ak by nesúvisel s produkciou piva. Kupec Matej zo Svinej (Mathias de Swyna) kúpil aj dve vel'ké kade na prípravu sladu a dve na varenie (duo dolia magna pro braxacione cerevisie et duo caldaria). Potom dvanást' vel'kých nádob (XII capisteria magna) a všetko d’alšie, čo bolo potrebné k produkcii piva (omnia alia suppelectilia spectantes ad braxacionem). V pivnici pod sudmi mal dve d’alšie nádoby (longa capisteria sub vasis), tri kade (tria dolia), jedenást' sudov (XI vasa), dva stoly (duas mensas) a dve lavice (duo sedilia alias Sidei dieta), prázdnu misu (unum almarium scutellarum vacuum) a dve vol'né ležadlá (duas spondas eciam vacuas). Ďalej 22 gbelov sladu (XXII cubulos brasii), štyri prázdne sudy (quatvor tonnellas vacuas) a všetko, čo súviselo s varením či sušením sladu (omnia spectantia ad braseatorium et ad siccatorium in quo brasium siccatur). Dohodli sa aj na predaji ôsmich nezasiatych jutrách zeme (VIII iugera non seminata), d’alších vel'kých nádobách na letnú pšenicu (aliquot capecias de siligine estivali) a na štyroch gbeloch pšenice určenej na výsadbu (quatvor cubulos pro seminatura), ktoré mali dat' novému kupcovi (EVJ II, 169-170).

Jednotlivé položky v prešovskej účtovnej knihe z 15 . storočia predstavovali hnutel'ný majetok, zlaté a strieborné predmety, textil, plátno, ryby, chlieb, víno atd', ale často to bol aj polsud piva, zakúpený napríklad stavitel'om mostu cez Torysu pri obci Petrovany v roku 1499 (pro medio vase cervisie in subsidium disponentibus pontem prope villam Sent Peter XLV. den), alebo $\mathrm{v}$ roku 1516 nemenovaným palatínom (pro cervisia domino pallatino donata fl. II. den. VIII; Iványi 1917, 252).

V účtovnom denníku zo stavby farského Kostola sv. Mikuláša v Prešove vedenom od roku 1502 sa spomínali na troch miestach aj sudy piva. Jeden v hodnote 48 denárov dostali tí, čo pálili vápno (unum vas cerevisie pro den. XLVIII). Môžeme predpokladat', že pivo dostávali vápenkári každý rok, lebo ak sa potom správy o nich odmlčali, tak v roku 1514 dostali tí istí majstri polsud piva za 28 denárov (pro medio vase cerevisie crematori cementi den. XXVIII). Magister Valentín, ktorý sa podiel'al na stavbe strechy kostolnej veže, dostal v roku 1514 rovnako polsud piva za 27 denárov (Magistro Valentino pro uno 1/2 vase cerevisie den. XXVII; Divald-Iványi $1927,53,69,70)$.

Testamentom z 2. októbra 1510 odkázala prešovská meštianka Magdaléna Grefen dom, $\mathrm{v}$ ktorom sa varilo pivo, s celou jeho výbavou (domus sue unacum suppellectilibus mediis ad braxationem cerevisie spectantibus). Venovala ho na výstavbu Kostola sv. Mikuláša, na oltár a iné zbožné ciele. Pamätala aj na dva sudy piva (duo vasa cervisie), z ktorých výt’ažok sa mal rovnako použit' za spásu jej duše (EVL II, 395-397 č. 1033). V d’alšom prešovskom testamente z 20. júna 1516 tiež odkazovali sud piva, tentoraz v súvislosti s františkánmi zo Solivaru (monachis de Sowor unum medium vas cervisie dare debebit; EVL II, 447-448 č. 1171). 
Na záver môžeme konštatovat', že tým, ktorí vykonávali tažkú fyzickú prácu, sa pridel’ovalo pivo. Tak to bolo aj v Prešove, ako nám o tom hovoria dobre zachované účtovné knihy z 15. a začiatku 16. storočia. Pivo dostávali lámači kameňa, murári, vápenkári, tesári na strechách, nádenníci a d'alší. V Bardejove stavali na začiatku 16. storočia nový organ, jeho stavitel' Jakub dostal okrem malej sumy peňazí aj tri menšie sudy piva, ako o tom hovoril záznam z roku 1517. Ich cena bola vyčíslená na 28,16 a 25 denárov (Ábel 1884, 545-546). Ked' začali na začiatku 16. storočia stavat' v Bardejove mestskú školu, v zachovaných účtoch sa rovnako spomínali i dodávky piva. Okrem peňazí dostali v roku 1520 tí, čo lámali kameň na jej stavbu, aj polsud piva za 38 denárov „na zdar a za tlčenie“ (pro salve et pulsu etc.). Tým, ktorí zabezpečovali a prepravovali vápno, dodali dva menšie sudy piva za 74 denárov (pro duobus mediis vasis cervisie den. LXXIIII). Jedným sudom piva za 75 denárov pamätali aj na maliara Jakuba, ktorý mal zariadit' výzdobu školy (pro cervisia unius vasis domino Jacobo pictori den. LXXV; EVI, $80,82)$.

Pivo stálo zhruba tretinu toho, čo víno. Tak o tom hovoril aj cenový výmer krála Ludovíta II. Limitatio de precio victualium z roku 1526 adresovaný mestu Šopron, ktorý stanovoval cenový strop potravín. Budínska pinta vína vyšla maximálne na 3 denáre, zatial' čo pinta piva na 1 denár. Pre porovnanie, pintu octu stanovili na 4 denáre (MR, 136-137 č. 11).

\section{Sud octu}

Tretím najčastejšie spomínaným nápojom $\mathrm{v}$ súvislosti so sudmi bol $\mathrm{v}$ stredoveku ocot (vasculum aceti). V písomných prameňoch mal však výrazne menšie zastúpenie. Aj sudy, v ktorých bol ocot naplnený, boli malých rozmerov. Našli sme ich uložené v kuchyniach alebo v pivniciach, a to v domoch alebo na hradoch. Ocot sa používal pri varení i v liečitel'stve. Zachytený ho máme tiež v dobovej ikonografii.

Pri vlámaní sa do domu v Budíne v roku 1508 odniesli okrem iných vecí aj osem vínnych sudov a d'alšie dva malé sudy s octom (KOV, 200-201).

Medzi vecami, ktoré mali dat' v roku 1513 kožušníkovi Gregorovi ako odškodné, mal byt' aj ocot. Sud plný octu mali rozdelit' a dat' z neho i tomuto kožušníkovi za rany, ktoré utrpel pri

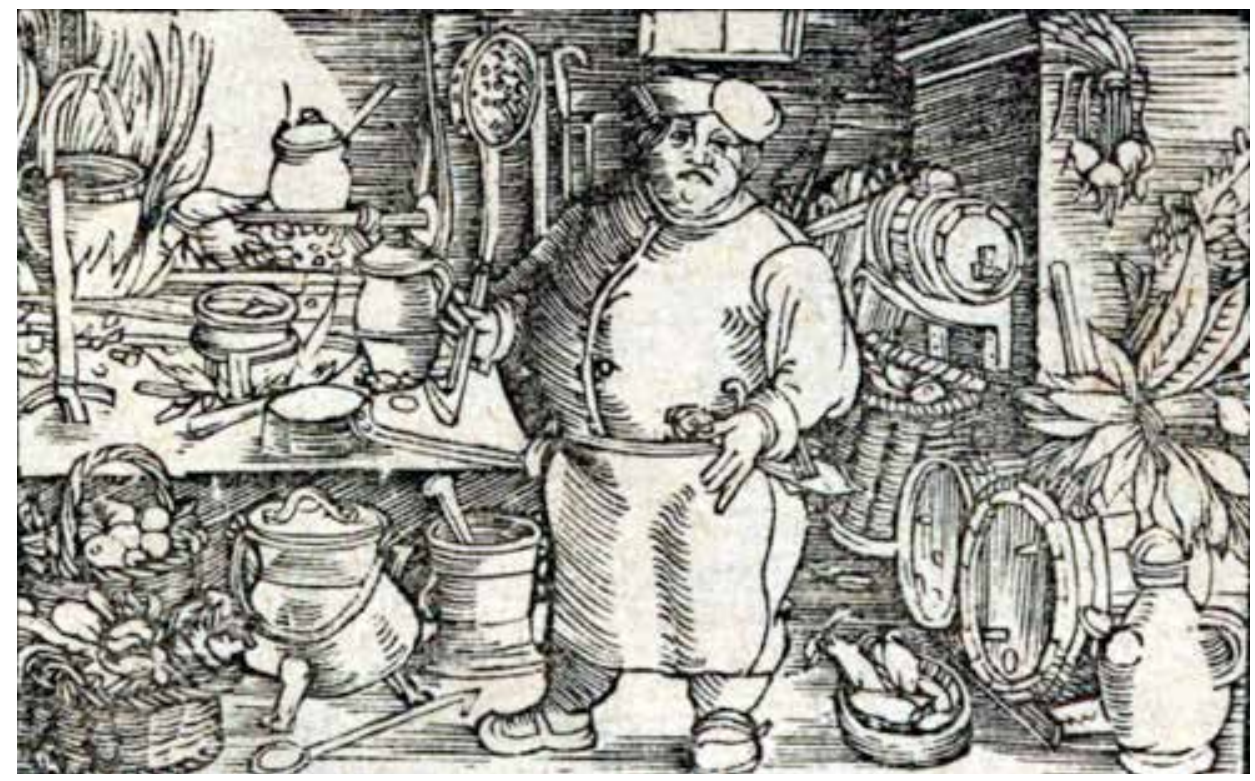

Obr. 2. Kuchyňa v roku 1530, využitie drevených sudov. Podl’a Platina 1530, titulná strana.

Abb. 2. Küche im Jahr 1530, Verwendung von Holzfässern. nach Platina 1530, Titelseite. 
nespravodlivom bičovaní, ked' riešili škody spôsobené bojom medzi Františkom Hédervárim a Ladislavom z Kaniže (HCsO II, 389, resp. 393 č. 423).

\section{Súdok s olejom}

Poslednú tekutinu, ktorú spomenieme v súvislosti so sudmi, je olej. Najčastejšie bol uskladnený v malých drevených súdkoch alebo v sklenených flašiach. V historických prameňoch vrcholného a neskorého stredoveku sme sa stretli s viacerými druhmi oleja. Druh oleja často nebol špecifikovaný (tunella olei), ale našli sme aj l'anový olej (tunella olei lini), konopný olej (pro oleo kanapi), makový olej (tunella olei papaveris), no najčastejšie bol vyrobený z olív (tunella olei olivae). V 16. storočí používali aj repkový olej (tunella rainffol), ako poukážeme d’alej v texte. Olej mohol byt' výnimočne naplnený $\mathrm{i} v$ medených flašiach.

V registri tridsiatkov starobudínskeho kastelána Jána Siebenlindera zo 4. marca 1436 sa spomínal jeden sud oleja, l’udovo nazvaný „krámový“ (tunella olei in vulgo taffernicz dicta), tiež jeden sud fíg (tunella ficuum), za ktoré mali odviest' po dva zlaté. Vyrubili poplatky aj za olej vo flaši, tentoraz nazvaný Triesterpant (lagena olei videlicet Triesterpant), aj za malú fl'ašu fíg (una lagena parva ficuum), d’alej fl'ašu mydla (lagena saponis seu smigmatis) a sušených hrozienok (lagena uvarum passarum; BOL, 270-272).

Konopný olej v troch fl’ašiach spomínali v Dolnom hrade Vyšehradu v roku 1490 (Nógrády 1998, 179-180). Medzi vecami dovezenými z Budína do Jágru v roku 1508 sa vyskytol aj jeden súdok olivového oleja a čo bolo zaujímavé, aj vak či vrece na uloženie vecí a na prenášanie súdku spomínaného oleja (pro sacculis ad res imponendas et ad disponendum vasculum predicti olei d. 10; EHP, 328). Do farnosti Seckau v Štajersku priniesli v roku 1526 jeden súdok lanového oleja od Viedenčanov (Roth 1951, 209).

\section{Obilniny a múka v drevenom sude}

„Kontajnery“ stredoveku - sudy - l'ud’om dobre poslúžili aj pri skladovaní potravín (a pevných látok všeobecne). Prvou z uskladnených komodít boli obilniny, resp. múka vyrobená z nich. Sudy mohli byt' uložené v sýpkach, stodolách, v kuchyniach, no nezaobišli sa bez nich ani v mlynoch. Okrem plátenných vriec ich tam využívali každodenne. Obilie sa v písomných správach spomínalo zväčša ako nešpecifikované, ak sa uvádzalo konkrétnejšie, tak sme našli najmä pšenicu, jačmeň a ovos.

V listine palatína Michala Országa z Guty (dnes Kolárovo) z 18. apríla 1482 sa spomínal istý Benedikt, ktorý zobral do mlyna $\mathrm{v}$ Kehide tri vrecia a dva sudy plné obilia na zomletie (tres saccos et duo vascula frumentis plena; ZVT, 620 č. 326). V inventári majetku biskupskej obce Gyöngyöspüspöki z roku 1508 sa nachádzali dva súdky octu a dva sudy múky (aceti duobus vasculis, farine duobus vasis; EHP, 345).

Zo 17. júla 1528 sa nám zachoval inventár hradu Gyula s položkami jeho potravinových zásob. V miestnosti, kde skladovali múku, mali devät’ sudov múky (viiij vasa farinae in eadem testudine farinarum). $\mathrm{V}$ hradnej kaplnke mali d’alšie tri sudy múky (iij vasa in sacella vel capella farinae). V kuchyni bolo k dispozícii 11 sudov múky (xj vasa farinae prope coquinam). V dlhej pivnici hradného paláca (pathlohazy/palotaházi pincze) mali desat' sudov múky naplnených tak, aby v každom z nich bolo nasypaných pät' gbelov múky (in unoquoque vase continentur cubuli quinque). Kol'ko múky bolo v roku 1528 na hrade Gyula? Spolu to činilo 165 gbelov múky a d'alších 15 gbelov otrúb (summa cubulorum ic lxv. xv cubuli furfuris; GVO, 133 č. 148).

\section{Ryby nakladané v sude}

Ďalšou komoditou uskladnenou v uzatváratel'ných sudoch boli solené, sušené a údené ryby, predovšetkým slede - alex, halex - nemecky haringy. Čerstvé ryby museli byt' odborne spracované, takáto úprava rýb potom umožňovala ich dlhodobejšie skladovanie, dala možnost' 
obchodovania s nimi. Ak bola ryba dostatočne zakonzervovaná, bola bez problémov schopná prevozu a uchovania po dobu dvoch až štyroch mesiacov. V obchodovaní s rybami sa mohol uplatnit' i dial'kový obchod, v ktorom dominovali predovšetkým hanzové mestá. Išlo o tovar, ktorý bol oblúbený, hodnotný, mal svoju cenu. V tridsiatkovom zozname príjmov zo Šopronu z roku 1490 sa pri dátume 13. marec spomínal príjem pol zlatky od dvoch sudov haringov (de duabus tunnellis allecum 1/2 fl.; SVT II/4, 340), teda pomerne vel'a.

V roku 1503 potrebovali zadovážit’ pre Jágerský hrad viacero vecí, z ktorých spomenieme potreby pre hradnú kuchyňu. Medzi nákupmi bol i jeden súdok s rybami, konkrétne sled’mi, ktorý vyšiel na 5 zlatých a 40 denárov (pro coquina castri emit unam tunellam de allecibus fl. quinque d. quadraginta; EHP, 173). Na Vianoce dostávalo Jágerské biskupstvo mimoriadne dávky vína a predovšetkým rýb, resp. peniaze na ich nákup. $\mathrm{V}$ účtovných knihách sa zachoval záznam Census nativitatis Domini z 25. decembra 1503, v ktorom sa spomínala kúpa viacerých sudov slaných rýb. Cena jedného takého suda rýb vychádzala na 15 či 16 zlatých (napr. zápis item Thalia pro uno vase piscium salsatorum dedit fl. sexdecim; EHP, 163).

V roku 1520 jeden z bardejovských priekupníkov podvádzal pri predaji sudu so sled’mi, do ktorého uložil namiesto rýb zviazané drievka. Takéto podvody sa predtým i potom stávali na rôznych miestach často (Gulyás 2014, 49). Úloha riešit' st’ažnosti rozhorčených občanov s priekupníkmi obvykle pripadla mestským magistrátom, ktoré prijímali opatrenia na nápravu daného stavu.

V roku 1539 máme spomenuté okrem predtým nešpecifikovaných rýb a dominujúcich sled'ov aj zriedkavejšie jesetery - o nich d’alej v texte.

\section{Súdok s medom alebo voskom}

Obchod s medom a včelím voskom patrili k najstarším druhom obchodu v Uhorsku. Obe položky predstavovali v stredoveku dôležitý a potrebný, no zároveň luxusný artikel. Prvý doklad o obchodovaní s nimi máme už z obdobia vlády král'a Imricha v listine z roku 1198 pre Ostrihom v súvislosti s vyberaním cla (Kerecsényi 1969, 19). Med bol sladidlom s pozitívnymi účinkami pre l'udský organizmus, ktorý sa využíval na prípravu jedál a v liečitel'stve. Včelí vosk zasa ludia potrebovali na výrobu sviec, ktoré od vrcholného stredoveku čiastočne nahrádzali staršie kahance. V stredovekej Európe boli lojové sviečky vyrobené z kuchynských tukov najčastejšou sviečkou, ale ich dym bol čierny a zapáchal. Včelí vosk sa v porovnaní so živočíšnym lojom pálil čisto, bez dymového plameňa. Sviečky z včelieho vosku boli ale drahé a pomerne málo l’udí si ich dovolilo mín̆at' v domovoch. Boli však hojne používané v chrámoch pri cirkevných obradoch. Ďalším využitím včelieho vosku bolo pečatenie listín a listov.

Zaujímavý historický prameň pochádza z roku 1255, ide o listinu s udelením trhového mýta Kláštoru Panny Márie na Margitinom ostrove v Budíne. Medzi mnohými inými komoditami nezabudli ani na med a vosk. Podl'a sadzobníka taríf bol za jeden sud medu „tunella mellis“ vyrubený rovnaký poplatok ako za vel'ký voz naložený volskými kožami. Za mieru vosku „mensura cerae“, ktorý l'udovo nazývali „masa“, sa malo odviest' tol'ko, kol'ko za voz zvieracích kožiek. Vosk delili podl'a kvality na čistý a nečistý (CDH IV/2, 311-312). Vysoké mýtne poplatky za med a vosk dokladali vzácnost' včelích produktov v stredovekom Uhorsku.

V roku 1329 sa v jednej zo stredovekých listín súvisiacich s mestom Miškovec (Miskolc-Alsózsolca) spomínal aj jeden súdok medu (una tunella mellis; MNL, DL 40559; Gyulai 1996, 321, pozn. 220). V tridsiatkovom zozname príjmov zo Šopronu z roku 1490 bol pri dátume 13. marec zapísaný poplatok za pät' súdkov medu 1 zlatý a 40 denárov ( $V$ tunnellis mellis I $f$ l. et XL den; SVT II/4, 340).

V menších sudoch sa okrem medu prenášali i samotné včelstvá. Z roku 1500 máme správu z účtovnej knihy hradu Jáger, ktorá znela takto: „Bolo tu dvadsat'štyri včelstiev, z ktorých priviezli šestnást's polsudom, nateraz tu zostáva osem na predaj“ (Item ibidem fuerunt apes 24, de quibus importarunt con medio vase sexdecim, adhuc restant ad vendendum octo; EHP, 141-142). 
V inventári jágerského panstva z roku 1508 sa nachádzalo aj 20 sudov kvasenej kapusty (caules salsati cum vasis), šest' plných menších sudov medu (mel media vasa plena) a d’alšie štyri malé súdky medu (duo parva plena et duo alia parva usque ad medietatem), jeden a pol menšieho suda starého tuku (arvina antiqua unum vas cum medio) a jeden sud nového tuku, asi bravčového (arvina nova medium vas). Takže včelieho medu bolo na hrade nadštandardne vel'a. Do inventáru zapísali aj celú plejádu koní a vozov, ktoré panstvu patrili. Kone i vozy boli rozdelené podl'a svojho druhu (EHP, 341).

\section{Iné komodity v sude}

Obchod s kamennou sol’ou bol v stredoveku špecifickým druhom obchodu, ktorého výskum by si zaslúžil širší priestor. Spomenieme ho iba okrajovo a to v súvislosti so sudmi. Sudy kamennej soli (lat. cupa, vasculum salis, nem. Salzküfl, Salzkifl, mad'. sóhordó, sóbödön), ktoré prevážali naložené na voze, spomínali v daňových a mýtnych predpisoch krála Bela IV. týkajúcich sa Győru a pril’ahlej stolice. Nájdeme ich v listinách zo 7. mája 1242 a tridsiatkovom výmere z roku 1255 , kde sa stanovilo, aká čast' a komu mala z predaja pripadnút'. Nezabudli na rábskeho župana (Szávay 1896, 146-147, 219-220). Vozy so sol'ou spomínali aj v trhových a mýtnych výsadách pre gemerské mestečko Putnok od Ladislava IV. z roku 1283 (AKO II/2-3, 315-316).

Kyslú kvasenú kapustu naplnenú v sudoch, konzumácia ktorej mala stáročnú tradíciu, sme už spomínali. Základom všetkých receptov k jej príprave bola kuchynská sol' a rasca. Našli sme ju v kuchyniach domov a hradov, takže tvorila rozšírenú súčast' stravovania. Zmienili sme sa aj o bravčovom tuku naplnenom v drevených sudoch alebo súdkoch.

Z komodít určených na obživu, uskladnených v drevených sudoch, sa v inventári Horného hradu Vyšehrad zo 7. augusta 1490 nachádzali tri sudy prosa, v Dolnom hrade Vyšehradu tri sudy octu, jeden sud prosa, jeden sud hrachu a v troch flašiach konopný olej (Nógrády 1998, 179-180).

Na majetkoch biskupstva v Jágri ukladali v roku 1508 do sudov aj ovocie a plody z bohatej úrody (fruges prompte vasa duo, [...] media pars stabuli est plena cum frugibus; EHP, 344).

Zo 17. júla 1528 pochádza inventár hradu Gyula so spísaným stavom jeho potravinových zásob a delostreleckej výzbroje. $\mathrm{V}$ budove, kde boli uchovávané potraviny (in domo ubi comestibilia usualia conservantur), skladovali jeden súdok so starším tvarohom (vasculum cum thuroh antiquum; GVO, 132 č. 148). V dome správcu hradu (in domo dispensatoris) sa nachádzal súdok so starou kyslou kapustou (vasculum cum caulibus salitis et antiquis) a súdok so semenami borievky (vasculum cum granis junyperi). V hradnej kuchyni mali sud na uchovávanie drahocennej vody (vas in coquina pro conservatione aquae) a d'alší riad na jej prenášanie a naberanie. Tiež tam mali jeden sud octu (vas aceti in coquina; GVO, 133 č. 148). V hradnej záhrade pestovali plodiny, ktoré vyslovene menovali: vinič, repu, kapustu, cibul'u, jablká, hrušky, cesnak a iné plody (vina, rapas, caules, cepas, poma, pira, alleum et reliqua universa genera fructuum). $\mathrm{Na}$ hrade bola aj kúpel'ňa, v ktorej bola umiestnená vyhrievaná pec s medeným kotlom a drevenou kad'ou, v ktorej sa dalo okúpat' (balnea stuba, i caldar cupreum magnum cum fornace collocatum, i doleum in quo balneantur; GVO, 134 č. 148).

Dňa 11. júna 1539 schválil král' Ferdinand I. register tridsiatkov pre Slavóniu a Chorvátsko, do ktorého zapísali vel'a druhov tovaru. Viacero komodít prepravovali v sudoch alebo súdkoch. Dokument dokladal, ako fungoval dial'kový obchod a aký tovar prenášali cestami z juhu Európy do Uhorska a naopak. Od vel'kosti vyrubeného mýta bolo možné odvodit' aj vel'kost' úložných nádob, teda aj sudov. V dokumente použitá terminológia bola totiž diferencovaná aj objemovo: vasa (maior) - vasa media - tunella, i clo bolo zväčša vyrubené v pomere 2 zlaté - 1 zlatý 25 denárov. Všetok tovar bol dodávaný v stanovených objemových jednotkách, v 16. storočí totiž vzrástla potreba presnejšej meratel'nosti a porovnatel'nosti. V tomto dokumente možno objemové miery a váhy už viditel’ne rozlíšit' (Kubinyi 1975, 51). Aj štátna moc mala záujem na presnosti, lebo z nej finančne profitovala. 
S akými komoditami naloženými v sudoch sa obchodovalo? Uvedieme ich podla zapísaného poradia: mandle pestované v Stredomorí (De tunella amigdali), sušené hrozná (uvae passae), olej (olei), ryža, jeden z najstarších dokladov obchodu s ryžou, pravdepodobne z Pádskej nížiny (risi), slede (alecis), mydlo (smigmatis), kamenec, žlté farbivo (aluminis), kapar (kapomeae), granátové jablká (pomi granati), tamjan, kadidlo (thuris), dubienka (gallis), smola, živica (gumi), sušené hrozienka, sušak (de chybabo, nem. Zibebe), benátske gaštany (castaneis Venetianis), pomaranče (tunella pomi narancei), malvazijské víno, známe biele víno (de tunella malmatici), repkový olej (de tunella rainffol, nem. Rüböl), vyza, jeseter (de uno vase husonum), slané ryby (de uno vase piscis saliti), med (de quartale mellis), loj (de pondere sepi, tunella sepi), syr (de pondere casei, tunella casei). Aj z tohto zoznamu vysvitá, že v prvej polovici 16. storočia boli sudy stále najčastejšie používanou „obalovou“ prepravkou (Horvat 1910, 232-233).

\section{Sud ako súčast’ hradnej výzbroje}

Témou nášho príspevku sú síce nápoje a potraviny, ale nemožno nespomenút' d’alšie využitie drevených sudov. Z iných materiálov uložených v týchto nádobách spomenieme najmä potreby k vojenskej obrane hradov. Začneme hradom Vyšehrad a jeho inventárom zo 7. augusta 1490. V Hornom hrade uskladňovali štyri sudy pušného prachu, v Dolnom hrade jeden sud síry, jeden sud so zápalnými šípmi a jeden sud so zápalnými gulami. Z iných zriedkavostí mali v Král'ovskom paláci v podhradí v sude uloženú čast' sklenenej výplne okien, tzv. vitráž. Súviselo to zrejme s renesančnou prestavbou paláca, ktorú medzi rokmi 1476 až 1484 uskutočnil král' Matej Korvín (Nógrády 1998, 179-180).

Zo zachovaného inventára výzbroje hradu Jajce v strednej Bosne zo 7. júna 1493 vyplýva, že vel’a sudov, súdkov a kadí potrebovali na uskladnenie vecí k obrane (CDP IV, 97-99 č. 63). Skladovali tam aj látky potrebné na výrobu pušného prachu, sanitru a síru, i hotový pušný prach. Sanitra (sodium nitrate, t. j. dusičnan sodný alias čílsky liadok, $\mathrm{NaNO}_{3}$ ) bola uskladnená na viacerých miestach najmenej v desiatich kadiach a piatich sudoch. Síru mali naplnenú v piatich sudoch a jednej poškodenej kadi (sulpura quinque vaseculos et unum doleum cum parvo defectu). Spolu tri a pol suda pušného prachu mali už pripravených, teda namiešaných. V dome s dvoma „oblúkmi“ (in domo arcuparis) mali uskladnených d’alších devät' sudov hotového pušného prachu, ktorý vyrobil magister Bartolomej (pulveris pixidorum, quos novissime magister Bartholomeus edidit, vascula novem). Na hrade sa nachádzali i d’alšie veci v sudoch. V štyroch mali uložený plot na stavbu bariéry, latinsky sepes, v dvoch boli uložené dve svietidlá duas lampades candelarum, v štyroch sudoch zasa gule do hákovníc globorum bombardicorum, l'udovo nazývané zakallu golobis (CDP IV, 98 č. 63; Pásztor 1970, 653).

Inventár hradu Jáger z roku 1508 evidoval aj jeho zbrojný arzenál, ktorý mohli obrancovia využit' v prípade nutnosti obrany hradu. Register vecí poskytol zaujímavý pohl'ad na využitie drevených sudov mimo nápojov a potravín (EHP, 342-343). V sudoch mali rovnako uložené všetky tri látky potrebné na výrobu pušného prachu, sanitru, síru a drevné uhlie. Sanitra bola naplnená v štyroch sudoch a jednom sude polovičnej vel'kosti (saletrum cum vasculis quattuor cum medio), síra rovnako v štyroch sudoch a jednom sude polovičnej vel'kosti (sulphurea cum vasculis quattuor cum medio) a drevené uhlie v sude strednej vel'kosti (carbones cum una media tunella). Pušný prach si teda tiež vedeli vyrobit' sami. Okrem toho mali už pripravený prach naplnený v d’alších dvanástich sudoch. Medzi horl’avé látky môžeme zaradit’ aj živicu z borovicovitých stromov uloženú v jednom sude (fenyewzurok cum vasculo). V d’alšom sude mali viacero druhov šípov (et super pavimentum in copia sagitte artium cum tunella una), železné gule strednej vel'kosti boli uložené v ôsmich debnách (globi ferrei mediocres cum ladulis) a väčšie železné gule nakládli aj do suda (globi ferrei maiores cum tunella). Všetky veci mali k dispozícii, obrancovia ich mohli využit' v prípade vojenského ohrozenia (EHP, 342-343).

Podl'a inventáru hradu Jelení kameň (Zarweskew, dnes Szarvaskő) z roku 1508 boli na hrade okrem iných vecí štyri sudy šípov (sagitte cum vasculis), jeden a pol suda strelného prachu (pulveres cum vasculis uno cum medio), dva menšie sudy octu (media vasa aceti), pät' a pol suda 
vína (vina integra cum medio) a jedna malá kad’a kvasenej kapusty (caules salsati cum parvo dolio; EHP, 341-342).

Z roku 1528 sa nám zachoval, ako sme už spomínali, inventár hradu Gyula, teda stav jeho potravinových zásob a delostreleckej výzbroje. Kompetentný človek prechádzal jednu hradnú miestnost' za druhou, zapísal veci z veže, podkrovia, vo vnútri hradieb, v niektorých miestnostiach, v kaplnke, náradie a potraviny v kuchyni, tiež sa zmienil o kúpel’ni hradu, jeho záhrade a podobne (GVO, 131-134 č. 148). Početný stav materiálu a hojnost' zásob opätovne vykázali aj 23. mája 1554 (GVO, 239-240 č. 300).

V roku 1528 uchovávali v hradnej veži 22 sudov s pušným prachom, okrem toho jeden súdok ,nie celkom plný “ síry, tiež jeden hrniec so sírou. V „tmavej“ miestnosti mali navyše ešte d’alších trinást' sudov pušného prachu, z ktorých jeden nebol plný. Prach mali aj v „dlhom sude“ z tretiny naplnenom, v 62 vreckách a dvoch hrncoch. K výrobe pušného prachu skladovali aj sanitru. Zaujímavý je údaj o 38 sudoch so smolou, l’udovo nazývaných „šiška“ (xxxviii vasculi vulgari tobos cum pice; GVO, 131 č. 148). Vo veži hradu Gyula, ktorú nazvali Cigán (in turri Zygan), mali uložený aj jeden drevený sud s vápnom (vas cum cymento; GVO, 134 č. 148). Využívali ho pri oprave hradných múrov. Uhorská strana musela utrpiet' značnú stratu, ked' hrad v roku 1566 obsadili Turci a vlastnili ho až do roku 1695.

\section{Záver}

Na záver možno konštatovat', že mnoho zachovaných historických prameňov potvrdilo všestranné využitie sudov v stredovekom Uhorsku. Pri analýze sme vychádzali z dvoch stoviek písomných správ od 12. storočia do prvej polovice 16. storočia. Medzi prameňmi sme mali listiny, daňové súpisy, desiatkové súpisy, zoznamy mýtnych poplatkov, testamenty, inventáre hradov a domácností, pozostalostné súpisy, mestské knihy, účtovné knihy a iné. Súbor prameňov použitých pre náš výskum sme d’alej nerozširovali, hoci zo stredoveku ich máme zachovaných omnoho viac. $Z$ kapacitných dôvodov sme pracovali iba s vybranou vzorkou.

Najčastejšie sa $v$ sudoch uskladňovali nápoje, predovšetkým víno, omnoho menej pivo a najmenej ocot a olej. Z potravín to boli najmä obilniny a múka, potom ryby, včelí med a vosk, kamenná sol', kyslá kapusta, ovocie a d’alšie plody, tuk, syr a semená rôznych rastlín. Sudy tvorili dôležitú výbavu hradov aj preto, lebo slúžili na uskladňovanie vojenských potrieb: smoly a živice, gúl' do diel alebo hákovníc, šípov, no predovšetkým troch látok potrebných k výrobe pušného prachu - síry, sanitry a dreveného uhlia.

Čo sa týka vel'kosti jednotlivých sudov, najstaršie písomné správy neumožňujú ich bližšiu objemovú špecifikáciu, lebo v nich použitá terminológia nebola jednoznačná. Pojmy vas, tunella a vasculum boli často významovo zamieňané. Aj poplatky za rovnaký objem tovaru mohli byt' $\mathrm{v}$ historických prameňoch diametrálne odlišné. Väčšia diferenciácia vel'kostí nádob prebiehala až v 15. storočí a k prvotnej presnosti viedla až v prvej polovici 16. storočia. V ranom novoveku vyvstala väčšia potreba merania a váženia v súvislosti s narastajúcim počtom obchodných artiklov. Štátna moc tiež mala záujem na presnejšom rozlišovaní objemov a vel'kostí sudov, lebo si z nich nárokovala zákonné poplatky, dane a clá. Na začiatku novoveku sa dopyt po sudoch zvýšil, preto narástol aj počet debnárov. Zvýšil sa i obrat na jarmokoch a trhoviskách.

Čím môže byt' historický výskum využitia sudov nápomocný archeologickému bádaniu? Drevené sudy sa nám až na niekol'ko výnimiek rozpadli, zo stredoveku sú zachované v európskych múzeách iba sporadicky. Ak nemali železné obruče, neboli úplne pevné, bola iba malá šanca na zachovanie ich drevených zvyškov. Preto práve historický výskum materiálnej kultúry stredoveku a každodennosti umožňuje vytvorit' spol'ahlivé závery. Navyše, dobovú terminológiu archeológia nezachytí. 


\section{Pramene a literatúra}

ÁBEL, J., 1884: Mütörténeti adatok a XV. és XVI. századból, Magyar Történelmi Tár 7, 525-546.

AKO: Az Árpádházi királyok okleveleinek kritikai jegyzéke II/2-3, 1272-1290 (Szentpétery, I., ed.). Budapest 1961 .

BARACZKA, I., 1966: A budai Nádasdy-ház számadása, 1530. IX. 30-1531. I. 13. In: Tanulmányok Budapest Múltjából 17, 247-272. Budapest.

BAUM, H.-P., 1999: Böttcher. In: Lexikon des Mittelalters. Studienausgabe. 2. Band, 490-492. Stuttgart - Weimar.

BCsL: A Balassa család levéltára 1193-1526 (Borsa, I., ed.). Budapest 1990.

BOL: Budapest történetének okleveles emlékei III, 1382-1439 (Kumorovitz, L. B., ed.). Budapest 1987.

BORSA, I., 1986: A szenyéri várkastély öt leltára a XVI. századból. Forrásközlemény. In: Somogy megye múltjából - Levéltári évkönyv 17, 73-85. Kaposvár.

CDA: Árpádkori új okmánytár. Codex diplomaticus Arpadianus continuatus I, 1001-1235 (Wenzel, G., ed.). Pest 1860.

CDH: Codex diplomaticus Hungariae ecclesiasticus ac civilis IV/2 (Fejér, G., ed.). Budae 1829.

CDP: Codex diplomaticus partium regno Hungariae adnexarum. Magyaroszág melléktartományainak oklevéltára 4: Banatus castrum et oppidum Jajcza, 1450-1527 (Thallóczy, L.-Horváth, S., edd.). Budapest 1915.

CIDLINSKÁ, L., 1989: Gotické krídlové oltáre na Slovensku. Bratislava.

DIVALD, K.-IVÁNYI, B., 1927: Az eperjesi Szent Miklós-templom. In: Az Országos Magyar Szépművészeti Múzeum Évkönyvei 4, 1924-1926 (Petrovics, E., ed.), 30-70. Budapest.

EHP: Estei Hippolit püspök egri számadáskönyvei: 1500-1508. A Heves Megyei Levéltár forráskiadványai 4 (Kovács, P., ed.). Eger 1992.

EVI: Adatok Eperjes város középkori iskolaügyének történetéhez (Iványi, B., ed.), Magyar Történelmi Tár 1911, 12, 67-88.

EVJ: Eperjes szab. kir. város jegyzőkönyve II, 1424-1509 (Iványi, B., ed.), Magyar Történelmi Tár 1909, 10, 161-183.

EVL I: Eperjes szabad királyi város levéltára, 1245-1526 (Iványi, B., ed.). Szeged 1931.

EVL II: Eperjes szabad királyi város levéltára, 1245-1526 (Iványi, B., ed.). Szeged 1932.

FCsO: A Frangepán család oklevéltára II, 1454-1527. Hamis oklevelek, 1209-1481 (Thallóczy, L.-Barabás, S., edd.). Budapest 1913.

GULYÁS, L. Sz., 2014: Írott szabályok és íratlan normák a 15.-16. századi mezővárosi kereskedelem. In: Urbs - Magyar várostörténeti évkönyv 9. Normakövetés és normaszegés - Válogatás a norma, normakövetés és normaszegés a városi életben c. konferencia előadásaiból, 29-59. Budapest.

GVO: Gyula város oklevéltára, 1313-1800 (Veress, E., ed.). Budapest 1938.

GYULAI, É., 1996: Miskolc középkori topográfiája. Termelés és kereskedelem a középkori Miskolcon. In: Miskolc története I. A kezdetektől 1526-ig (Kubinyi, A., ed.), 165-364. Miskolc.

HCsO: A Héderváry-család oklevéltára II (Závodszky, L., ed.). Budapest 1922.

HOLUB, J., 1960: A bortermelés Zala megyében 1526 előtt. In: A Göcseji Múzeum jubileumi emlékkönyve 1950-1960, 181-202. Zalaegerszeg.

HORVAT, R., 1910: Hrvatske carine god. 1539, Vjesnik 12, 230-235.

IVÁNYI, B., 1917: Jogtörténeti vonatkozások Eperjes város középkori számadáskönyveiben. In: Emlékkönyv Fejérpataky László életének hatvanadik évfordulója ünnepére (Szentpétery, I., ed.), 243-262. Budapest.

- 1918: Eperjes Város középkori építkezései és építészei, 1. közlemény, A Múzeum és Könyvtári Értesítő $12,112-127$.

JANOTKA, M.-LINHART, K., 1984: Zapomenutá řemesla: vyprávění o lidech a věcech. Praha.

- 1987: Řemesla našich předků. Praha.

KELLER, A., 1990: A Jánosréti mester és köre a müvészettörténeti szakirodalomban, Ars Hungarica 2, 187-200.

KEMÉNY, L., 1891: A reformáció Kassán. Oklevéltárral. Kassa.

KERECSÉNYI, E. H., 1969: A népi méhészkedés története, formái és gyakorlata Nagykanizsa környékén. Budapest.

KERNY, T., 1992: Kéziratos és rajzi dokumentumok a jánosréti templom berendezésének történetéhez, Ars Hungarica 1, 115-120.

KIS, P.-PETRIK, I., 2008: Kiadatlan Árpád-kori oklevelek a főváros történetéhez, 1192-1298. In: Szívvel és tettel. Tanulmányok Á. Varga László tiszteletére, 13-44. Budapest - Salgótarján. 
KOV: Középkori oklevelek Vas megyei levéltárakban. I. Regeszták a vasvári káptalan levéltárának okleveleiről (1130) 1212-1526 (Kóta, P., ed.). Szombathely 1997.

KUBINYI, A., 1975: Budapest története a későbbi középkorban Buda elestéig (1541-ig). In: Budapest története II. A későbbi középkorban és a török hódoltság idején, 7-240. Budapest.

LUKAČKA, J., 2016: Matúš Č́k Trenčiansky. Bratislava.

MÁLYUSZ, E., 1971: Egyházi társadalom a középkori Magyarországon. Budapest.

- 1929: A szlavóniai és horvátországi középkori pálos kolostorok oklevelei az Országos Levéltárban: negyedik közlemény, Levéltári Közlemények 7, 3-4, 278-311.

MES: Monumenta Ecclesiae Strigoniensis II (Knauz, F.- Dedek, L. C., edd.). Strigonii 1882.

MNL: Magyar Nemzeti Levéltár Budapest, Magyar Országos Levéltár, DL-DF collectio diplomatica Hungarica.

MOLNÁR, I., 1975: A magyarországi pálosok „Zöld kódex”-ének Somogy megyei regesztái, Somogyi Múzeumok Közleményei 2, 217-233.

MR: Magyar regesták. A Szepesi Káptalan, Jászai s Leleszi Conventek, Kassa és Sopron városok s több magánosok levéltáraiból s gyüjteményeiből II, 1228-1643 (Horváth, M., ed.), Magyar Történelmi Tár, 1862, 11, 125-196.

NÓGRÁDY, Á., 1998: Mátyás kincsek a visegrádi vár 1490. évi leltárában. In: Tanulmányok Borsa Iván tiszteletére (Csukovits, E., ed.), 177-180. Budapest.

OF: Okmánytár a Fuggerek magyarországi nagykereskedése és rézvállalatának történetéhez I (Wenzel, G., ed.), Magyar Történelmi Tár, 1882, 5, 622-669.

PACKHEISER, M., 2008: Böttcher. In: Das alte Handwerk: Von Bader bis Zinngießer (Reith, R., ed.), 33-37. München.

PÁSZTOR, J., 1970: A magyar katonai terminológia kialakulása. A hadi élet szavai Zrínyi Miklós koráig. A szerző 1968-ban elfogadott doktori disszertációja alapján készült dolgozat, Hadtörténelmi Közlemények 17, 4, 634-676.

PLAČEK, M., 2017: Nejprve dvorec - nakonec pozdně renesanční dependencie - Kněžice/Knieschitz zunächst ein Herrenhof - schließlich eine Dependance der Spätrenaissance, AH 42, 523-537.

PLATINA, B., 1530: Von allen Speisen und Gerichten etc. Augsburg.

ROTH, B., 1951: Das Seckauer Oblaywesen. In: Ergänzungsband 2/2. Festschrift zur Feier des 200-jährigen Bestandes des HHStA, 2. Bände (Santifaller, L., ed.), 197-225. Wien.

SLIVKA, M., 2016: Poznámky k najnovšej historiografii o templároch, johanitoch a antonitoch na Slovensku, Kultúrne dejiny 7, 197-216.

SVT: Sopron szabad királyi város története II/4. Különféle számadások és adójegyzékek 1454-től 1495-ig (Házi, J., ed.). Sopron 1936.

SZÁVAY, Gy., 1896: Győr. Monográfia a város jelenkoráról a történelmi idők érintésével. Győr.

TRONNIER, C., 2015: Das Fass: „Der Container“ des Mittelalters und der Frühen Neuzeit. In: BGH Freund (Bremer Geschichtenhaus), 3. März 2015, Der lebendige Blog zum lebendigen Museum im Bremer Schnoor. Dostupné z: https://freundeskreisbremergeschichtenhaus.wordpress.com/2015/03/03/das-fassder-container-des-mittelalters-und-der-fruhen-neuzeit/, cit. 26. 11. 2017.

VÁLKA, M., 2014: Homo faber. Tradiční zemědělství a lidová výroba. Brno.

VER: Veszprémi regeszták, 1301-1387 (Kumorovitz, L. B., ed.). Budapest 1953.

WITTHÖFT, H., 1999: Faß. In: Lexikon des Mittelalters. Studienausgabe, 4. Band, 303. Stuttgart - Weimar. ZsO I: Zsigmondkori oklevéltár I, 1387-1399 (Mályusz, E., ed.). Budapest 1951.

ZsO IV: Zsigmondkori oklevéltár IV, 1413-1414 (Mályusz, E., ed.). Budapest, 1994.

ZsO V: Zsigmondkori oklevéltár V, 1415-1416 (Mályusz, E., ed.). Budapest, 1997.

ZsO VII: Zsigmondkori oklevéltár VII, 1419-1420 (Mályusz, E., ed.). Budapest 2001.

ZsO VIII: Zsigmondkori oklevéltár VIII, 1421 (Borsa, I., ed.). Budapest, 2003.

ZVT: Zala vármegye története. Oklevéltár 2, 1364-1498. Budapest 1890.

\section{Zusammenfassung}

\section{Holzfässer und ihre Nutzung bei der Lagerung von Getränken und Lebensmitteln (im mit- telalterlichen Ungarn)}

Die universale Nutzung von Fässern im mittelalterlichen Ungarn wird von vielen erhaltenen historischen Quellen bestätigt. Bei ihrer Untersuchung haben wir uns auf Handelswaren 
konzentriert, die in den Fässern gelagert wurden. Unsere Analyse basiert auf zweihundert schriftlichen Berichten aus der Zeit ab dem 12. Jahrhundert bis zur ersten Hälfte des 16. Jahrhunderts. Die von uns untersuchten Proben stellten, obwohl sie sich noch erweitern ließen, eine solide Grundlage für eine tiefergehende Untersuchung dar. Zu den herangezogenen Quellen zählten Urkunden, Steuerverzeichnisse, Zehntverzeichnisse, Mautregister, Testamente, Inventare von Burgen und Haushalten, Nachlassverzeichnisse, Stadtbücher, Rechungsbücher u.a. Die Bestimmung des Fassungsvermögens der einzelnen Behältnisse wurde von uns jedoch nicht behandelt, da diese Frage eine eigene Arbeit verdienen würde.

Am häufigsten wurden Fässer für Getränke verwendet, vor allem für Wein, bedeutend weniger für Bier und am wenigsten für Essig und Öl. Die Fässer wurden aufgeführt als größer, mittel oder kleiner, der darin gelagerte Wein war entweder alt oder neu. Mit Weinfässern konnte man Steuern und den Zehnten entrichten, Schulden abbezahlen, verpfändetes Eigentum einlösen oder Schadensersatz leisten für einen Schaden, den jemand erlitten hat. Es war ein Vermögen, das seinen Wert auch über viele Jahre hinweg beibehalten hatte.

Von den Lebensmitteln waren es vornehmlich Getreide und Mehl, danach Fische, Bienenhonig und Wachs, Steinsalz, Sauerkraut, Obst und weitere Früchte, Fett, Käse und die Samen verschiedener Pflanzen. Die Liste der in den Fässern gelagerten Waren wurde von Getreide, bzw. dem daraus hergestellten Mehl angeführt. Die Fässer konnten in Kornspeichern, Scheunen und Küchen aufbewahrt werden, und auch in den Mühlen ist man nicht ohne sie ausgekommen. Neben Leinensäcken wurden sie dort tagtäglich verwendet. Frische Fische wiederum mussten speziell behandelt werden, da nur eine solche Verarbeitung der Fische ihre langfristige Lagerung möglich machte. Darüberhinaus ermöglichten die Fässer, die darin gelagerten Fische - vor allem Heringe - auf den Märkten feilzubieten. Auch das Einlegen von Sauerkraut wäre ohne diese Holzgebinde nicht ausgekommen.

Fässer bildeten einen wichtigen Bestandteil in der Ausstattung von Burgen, da sie zur Lagerung von Militärbedarf dienten. In ihnen wurden Peche und Harze, Kanonen- oder Gewehrkugeln, Pfeile und vor allem die drei für die Herstellung von Schießpulver nötigen Stoffe Schwefel, Salpeter und Holzkohle aufbewahrt. Die Versorgung der Burgen war jeweils unterschiedlich.

Was die Größe der einzelnen Fässer betrifft geben die ältesten schriftlichen Berichte keine nähere Auskunft über ihr Fassungsvermögen, da die darin verwendete Terminologie nicht eindeutig war. Die Begriffe „Vas“, „Tunella“ und „Vasculum“ wurden bedeutungsmäßig häufig gewechselt. Auch die Abgaben konnten in den historischen Quellen für gleiche Volumina diametral voneinander abweichen. Eine größere Differenzierung bezüglich der Größe der Gefäße erfolgte erst im 15. Jahrhundert und führte erst in der ersten Hälfte des 16. Jahrhunderts zu einer primären Genauigkeit. Im Frühmittelalter entstand im Zusammenhang mit der wachsenden Zahl von Handelswaren eine größere Notwendigkeit des Messens und Wiegens. Die Staatsgewalt hatte auch Interesse an einer genaueren Unterscheidung der Fassungsvermögen und Größen von Fässern, da sie davon die gesetzlichen Abgaben, Steuern und Zölle beanspruchte.

$\mathrm{Zu}$ Beginn der Neuzeit ist die Nachfrage nach Fässern noch gestiegen, weswegen auch die Zahl der Küfer zunahm. Die Umsätze auf den Jahrmärkten und Marktplätzen haben ebenfalls zugenommen.

Wodurch kann eine historische Untersuchung der Nutzung von Fässern der archäologischen Forschung hilfreich sein? Bis auf wenige Ausnahmen sind Holzfässer zerfallen, aus dem Mittelalter werden in den europäischen Museen nur sporadisch erhalten gebliebene Exemplare aufbewahrt. Wenn sie keine Fassreifen aus Eisen hatten, waren sie nicht ganz fest und die Chance, dass sich ihre hölzernen Überreste erhalten, war nur sehr gering. Aus diesem Grund ermöglichen es gerade historische Untersuchungen der mittelalterlichen Sachkultur und des Alltags, zuverlässige Schlussfolgerungen zu ziehen. Darüberhinaus wird die zeitgenössische Terminologie von der Archäologie nicht erfasst.

doc. Mgr. Jaroslav Nemeš, PhD., Katedra histórie Filozofickej fakulty Katolíckej univerzity, Hrabovská 1, SK 03401 Ružomberok, Slovenská republika, jaroslav.nemes@ku.sk 
